\title{
NO-synthasis/arginasis System in Plasma and Blood Lymphocytes in Women with Primary Infertility and Recurrent Pregnancy Loss with Ascariasis Presence
}

\author{
Valentyna Sklyarova, Rostyslav Chajkivskyj, and Pavlo Sklyarov
}

\begin{abstract}
-
Materials and methods: This is an investigation of 49 cases with confirmed ascariasis and pathology of reproductive system in the Lviv City Center for Family Planning and Human Reproduction Lviv Ukraine between January 2013 and December 2015.

Purpose : The aim of the study was to investigate changes in the L-arginine / NO synthase / arginase system in women with primary infertility and recurrent pregnancy loss with ascariasis presence in Ukraine.

Results : In women with recurrent pregnancy loss and women with primary infertility were observed significant activation of iNOS in lymphocyte lysates, an increase in nitrite anion production, and a decrease in $\mathrm{L}$-arginine content in the blood plasma and ascariasis compared with RPL and PI patients without ascariasis.

Conclusion : Ascariasis can be factor of the development of inflammation.
\end{abstract}

Index Terms - NO; Ascariasis; Infertility; Recurrent Pregnancy Loss.

\section{INTRODUCTION}

The L-arginine/ NO synthase/arginase system is key in the functioning of endothelial cells and is involved in the regulation of numerous processes in the body, including mechanisms of reproduction [13]. L-arginine is an essential amino acid necessary for spermatogenesis, embryonic and fetal development, growth and development of the fetus, as well as maintaining vascular tone and hemodynamics [4]. NO synthesized from L-arginine may be involved in follicular maturation and ovulation, as well as in the regulation of ovarian vessel tone and endometrium [1]. That is, the balance between the content of L-arginine in the blood plasma and the production of nitrogen oxide by endothelial cells is one of the factors involved in supporting the reproduction processes [15]. Blood lymphocytes maintain the immunological status of the organism due to their phagocytic activity, synthesis of pro- and antiinflammatory cytokines and NO secretion [2], [11], [12]. It has been noted that the activity of NO synthase and arginase in peripheral blood lymphocytes changes in conditions of autoimmune diseases in humans [5], and the concentration of L-arginine in blood plasma is significantly reduced upon infection and inflammation [3].

Ascariasis is one of the most common human parasitic infections in the world [6]. The persistence of ascarid eggs in the lower parts of the female reproductive system, as well as the presence of parasites there, can cause various local disorders, as well as affect the state of vascular endothelial cells, NO synthase / arginase, the activity of lipoperoxidation processes in lymphocytes and blood plasma [7].

The aim of the study was to investigate changes in the Larginine / NO synthase / arginase system in women with primary infertility and recurrent pregnancy loss with ascariasis presence in Ukraine.

\section{MAterials AND METHODS}

The studies performed in Lviv City Center for Family Planning and Human Reproduction, the Departments of Family Medicine and Clinical Affairs and Biochemistry of Danylo Halytsky National Medical University, Lviv, Ukraine. We examined 53 patients with recurrent pregnancy loss (RPL), including 28 women without ascariasis (A) (subgroup L) and 25 women with ascariasis (subgroup K), and 51 patients with primary infertility (PI): 27 women without ascariasis (subgroup P) and 24 women with presence of acarida invasions (subgroup S). Control group consistent 24 gynecological and somatically healthy women without pathology of reproduction. Biochemical research methods have included the determination of relevant targets in blood plasma and lymphocyte lysates.

The activity of NO synthases in lymphocyte lysates was determined according to the method of VV Sumbayev [8].

Studies on the activity of arginase were performed according to the method of Geyer J.W., Dabich D. [9]. The concentration of stable metabolite NO-2 as active NO was determined using Gris reagent [10] in blood plasma and lymphocyte lysate (dilution 1:10). Studies of L-arginine content in blood plasma and lymphocyte lysate were performed by the method of Aleynikov TL [16].

For the determination of antibodies to parasites (Toxocara canis, Giardia Lamblia and Ascaris lumbricoides), kits of Vitrotest Anti (Ramintech, Ukraine) were used.

Parasitological examination included coproscopy and enterobiasis examination. Each stool sample was developed using the methods of Kato, Füleborn, and Schulman [17]. Enterobiosis examination was performed using the adhesive tape method (according to Graham) and the method of perianal scraping (according to Torgushin) [18].

Statistical processing of results was performed using SPSS 7.0 and Microsoft Excel 2000. A literature review was conducted.

Published on April 13, 2020. 


\section{RESULTS}

In plasma of healthy women the concentration of nitrogen oxide was $21.2 \pm 1.4 \mu \mathrm{mol} / \mathrm{l}$, the total content of nitrite and nitrate of anions was $-23.2 \pm 1.9 \mu \mathrm{mol} / 1$, arginase activity was within the normal range (Tables 1,2 ).

TABLE 1 - CHANGES IN ARGINASE ACTIVITY, NITRITE ANION CONTENT AND BLOOD PLASMA L-ARGININE CONCENTRATIONS IN WOMEN WITH RECURRENT PREGNANCY LOSS AND PRIMARY INFERTILITY AND ASCARIASIS $(\mathrm{M} \pm \mathrm{M})$

\begin{tabular}{|c|c|l|l|}
\hline Examined groups & $\begin{array}{c}\text { Arginase } \\
\boldsymbol{\mu m o l} / \mathbf{m i n} \bullet \mathbf{m} \\
\mathbf{g} \text { protein }\end{array}$ & $\begin{array}{c}\text { L-arginine } \\
\boldsymbol{\mu g} / \mathbf{m l}\end{array}$ & $\begin{array}{l}\text { Nitrite anion } \\
\boldsymbol{\mu m o l} / \mathbf{l}\end{array}$ \\
\hline $\begin{array}{c}\text { Control group } \\
(\mathrm{n}=24)\end{array}$ & $0,28 \pm 0,05$ & $25,1 \pm 6$ & $14,8 \pm 0,9$ \\
\hline Subgroup P ( $=27)$ & $0,25 \pm 0,08$ & $24,7 \pm 7,8$ & $17,2 \pm 1,8$ \\
\hline Subgroup S ( $\mathrm{n}=24)$ & $0,23 \pm 0,05$ & $21,4 \pm 3,1$ & $20,6 \pm 0,4^{* \wedge}$ \\
\hline Subgroup L ( $=28)$ & $0,27 \pm 0,8$ & $24,1 \pm 3,6$ & $15,4 \pm 1,3$ \\
\hline Subgroup K ( $\mathrm{n}=25)$ & $0,22 \pm 0,05$ & $20,7 \pm 2,9$ & $21,2 \pm 0,7^{* \#}$ \\
\hline
\end{tabular}

Note $1: *-$ a significant difference $(\mathrm{p}<0.05)$ between the $\mathrm{S}(\mathrm{RPL}$ and A) women and the control group.

Note $2 . \wedge$ is a significant difference $(p<0.05)$ between the female subgroup $\mathrm{S}$ (RPL and A) and the subgroup P (non A).

Note 3 . \# is the difference $(p<0.05)$ between the female subgroup $K$ (RPL and A) and the subgroup L (non-A).

The concentration of L-arginine, a precursor for $\mathrm{NO}$ synthase and arginase in the blood of control women, was significantly higher $(3.4$-fold, $\mathrm{p}<0.01)$ than in lymphocyte lysates

The ratio between the plasma L-arginine concentration and the lymphocyte lysate in the blood of control women was 3.37. The sharp gradient between plasma L-arginine concentration and lysate indicates the high level of amino acid utilization and its need for lymphocyte metabolism.

Nitrite-anion content in blood plasma exceeded its concentration in lymphocyte lysate by $70 \%(\mathrm{p}<0.05)$. Arginase activity was slightly higher in lymphocyte lysates.

Therefore, the content of nitrite anion in the blood plasma and in the lymphocyte lysate is due to its synthesis from L-arginine eNOS localized in vascular endothelial cells and lymphocytes. The ratio of nitrite anion content in blood plasma and lysate was 1.43. Plasma arginase activity and lymphocyte lysate were not significantly different in healthy women.

The results of studies show that the state of NO synthase system in nonpregnant healthy women were characterized by the dominance of the activity of eNOS in lymphocytes, due to the absence in the blood of factors that activate iNOS, primarily microbial lipopolysaccharides, pro-inflammatory cytokines and hypoxia. iNOS activity in lymphocyte lysates was low (Table 2).

The activity of arginase did not change, and the concentration of L-arginine in the blood plasma decreased by $69 \%(\mathrm{p}<0.05)$, and in the lymphocyte lysate remained unchanged.

TABLE 2 - CHANGES IN ARGINASE ACTIVITY, NITRITE ANION CONTENT AND L-ARGININE CONCENTRATION IN LYMPHOCYTE LYSATES IN WOMEN WITH RECURRENT PREGNANCY LOSS AND PRIMARY INFERTILITY AND ASCARIASIS $(\mathrm{M} \pm \mathrm{M})$

\begin{tabular}{|l|l|l|l|}
\hline Examined groups & $\begin{array}{l}\text { Arginase } \\
\boldsymbol{\mu} \text { mol/min•m } \\
\mathbf{g} \text { protein }\end{array}$ & $\begin{array}{l}\text { L-arginine } \\
\boldsymbol{\mu g} / \mathbf{m l}\end{array}$ & $\begin{array}{l}\text { Nitrite anion } \\
\boldsymbol{\mu m o l} / \mathbf{l}\end{array}$ \\
\hline $\begin{array}{l}\text { Control group } \\
(\mathrm{n}=24)\end{array}$ & $0,20 \pm 0,06$ & $84,6 \pm 7,2$ & $21,2 \pm 1,4$ \\
\hline $\begin{array}{l}\text { Subgroup P } \\
(\mathrm{n}=27)\end{array}$ & $0,21 \pm 0,04$ & $79,4 \pm 5,5$ & $23,6 \pm 1,4$ \\
\hline Subgroup S ( $=24)$ & $0,18 \pm 0,05$ & $61,2 \pm 5,2^{* \wedge}$ & $26,8 \pm 0,5^{* \wedge}$ \\
\hline Subgroup L $(\mathrm{n}=28)$ & $0,22 \pm 0,05$ & $80,8 \pm 5,3$ & $23,5 \pm 0,8$ \\
\hline Subgroup K $(\mathrm{n}=25)$ & $0,19 \pm 0,04$ & $63,7 \pm 5,8^{* *}$ & $25,9 \pm 0,9^{* \#}$ \\
\hline
\end{tabular}

Note $1:{ }^{*}$ - a significant difference $(\mathrm{p}<0.05)$ between the S $($ RPL and A) women and the control group.

Note $2 . \wedge$ is a significant difference $(p<0.05)$ between the female subgroup $\mathrm{S}$ (RPL and A) and the subgroup $\mathrm{P}$ (non $\mathrm{A}$ ).

Note 3 . \# is the difference $(\mathrm{p}<0.05)$ between the female subgroup $\mathrm{K}$ (RPL and A) and the subgroup L (non-A).

This indicates that the concentration of L-arginine in the cytoplasm of lymphocytes is maintained at a stable level and with the increase of eNOS activity increases the supply of L-arginine from the blood plasma (Table 3).

In women with RPL without acarida invasion, the indicators of L-arginine content, anion nitrite, and arginase activity were not significantly different from those of control women. However, women in this group in lymphocyte lysate increased eNOS activity by $58 \%$ (p $<0.05$ ), compared with healthy subjects. The activity of iNOS and arginase did not change significantly. In women with PI without ascariasis, NO-synthase activity rates were at the level of data in patients with RPL.

Table 3 - CHANGES IN THE ACTIVITY OF NO SYNTHASES IN LYMPHOCYTE LYSATE IN IN WOMEN WITH RECURRENT PREGNANCY LOSS AND PRIMARY INFERTILITY AND ASCARIASIS $(\mathrm{M} \pm \mathrm{m})$

\begin{tabular}{|l|l|l|l|}
\hline Examined groups & $\begin{array}{l}\text { NOS } \\
\mathbf{n m o l} / \mathbf{m i n} \cdot \mathbf{m l}\end{array}$ & $\begin{array}{l}\mathbf{i N O S} \\
\mathbf{n m o l} / \mathbf{m i n} \cdot \mathbf{m l}\end{array}$ & $\begin{array}{l}\text { NNOS } \\
\mathbf{n m o l} / \mathbf{m i n} \cdot \mathbf{m l}\end{array}$ \\
\hline $\begin{array}{l}\text { Control group } \\
(\mathrm{n}=24)\end{array}$ & $0,76 \pm 0,17$ & $0,08 \pm 0,01$ & $0,67 \pm 0,18$ \\
\hline Subgroup P $(\mathrm{n}=27)$ & $1,15 \pm 0,27$ & $0,07 \pm 0,02$ & $1,06 \pm 0,25$ \\
\hline Subgroup S $(\mathrm{n}=24)$ & $1,2 \pm 0,09^{*}$ & $0,78 \pm 0,08^{* \wedge}$ & $0,42 \pm 0,15^{\wedge}$ \\
\hline Subgroup L $(\mathrm{n}=28)$ & $1,22 \pm 0,3^{*}$ & $0,08 \pm 0,02$ & $1,13 \pm 0,18$ \\
\hline Subgroup K ( $\mathrm{n}=25)$ & $1,21 \pm 0,17^{*}$ & $0,68 \pm 0,07^{*+}$ & $0,53 \pm 0,13^{+}$ \\
\hline
\end{tabular}

Note $1: *$ - a significant difference $(\mathrm{p}<0.05)$ between the S $(\mathrm{RPL}$ and A) women and the control group.

Note $2 . \wedge$ is a significant difference $(p<0.05)$ between the female subgroup S (RPL and A) and the subgroup P (non A).

Note 3 . \# is the difference $(p<0.05)$ between the female subgroup $K$ (RPL and A) and the subgroup L (non-A).

In women with primary infertility and ascarida invasion, plasma nitrite anion content increased by $14 \%(\mathrm{p}<0.05)$ and L-arginine concentration decreased by $20 \%(\mathrm{p}<0.05)$. At the same time, the lymphocyte lysate also increased the content of nitrite anion (by $20 \%, \mathrm{p}<0,05$ ), there was a tendency to decrease L-arginine and sharply increased the activity of iNOS $(\mathrm{p}<0,01)$ and decreased the activity of cNOS $(\mathrm{p}<0.05)$. Women with PI and ascariasis showed a $28 \%$ increase in nitrite anion content $(p<0.05), 8.5$-fold increase in iNOS activity $(\mathrm{p}<0.01)$.

The results obtained indicate that the presence of ascarida in women with primary infertility or with recurrent pregnancy loss causes a pro-inflammatory systemic reaction, which is manifested in an increase in nitrite-anion production due to increased activity of iNOS. secretory excretory products produced by ascarids are active substances that can directly or with the participation of proinflammatory cytokines activate iNOS of endothelial cells and lymphocytes. These processes are particularly dangerous in small vessels and capillaries of the uterus and 
ovaries, which can contribute to the development of infertility.

\section{DISCUSSION}

The endometrium of the uterus and fallopian tubes is a critical place in the infection of ascarids. Considering the results obtained, it is possible to consider ascaridosis as one of the factors of the occurrence of infertility and reproductive losses. We have shown that changes in the NOsynthase system occur in blood plasma and lymphocytes, indicating endothelial changes and the development of inflammation. The increase of nitrite-anion content, decrease of L-arginine content in blood plasma and increase of iNOS activity, nitrite-anion content and decrease of Larginine content in lymphocyte lysate give reason to talk about endothelial-lymphocytic dysfunction in women. And investigations in this field will be continued [14].

The inflammatory response of the lower parts of the reproductive system contributes to the violation of vaginal endoecology, increased proliferative processes, the level of pro inflammatory interleukins.

\section{CONCLUSION}

1. In healthy women, peripheral lymphocytes were dominated by eNOS activity, plasma nitrite anion content exceeded nitrite anion concentration in lymphocyte lysate by $28 \%$ ( p < $<0.05$ ), plasma arginase activity, and lymphocyte lysate , the plasma L-arginine concentration was higher $(69 \%, p<0.01)$ than in lymphocyte lysates.

2 . In women with recurrent pregnancy loss in lymphocyte lysate the activity of eNOS increased by $58 \%$.

3 . In women with recurrent pregnancy loss and women with primary infertility were observed significant activation of iNOS in lymphocyte lysates, an increase in nitrite anion production, and a decrease in L-arginine content in the blood plasma and ascariasis compared with RPL and PI patients without ascariasis. This may indicate the development of inflammation caused by ascarids.

\section{REFERENCES}

[1] Wu G., Bazer F.W., Davis T.A. Arginine metabolism and nutrition in growth, health and disease. Amino Acids. 2009. Vol. 37, № 1. P. 153 168.

[2] Bogdan C. Regulation of lymphocytes by nitric oxide. Methods Mol. Biol. 2011. Vol. 677. P. 375-393.

[3] Li P., Yin Y.-L., Li D. Amino acids and immune function. British J. Nutrition. 2007. Vol. 98. P. 237-252.

[4] Chandrasekharan UM, Wang Z, Wu Y, Wilson Tang WH, Hazen SL, Wang S, Elaine Husni M. Elevated levels of plasma symmetric dimethylarginine and increased arginase activity as potential indicators of cardiovascular comorbidity in rheumatoid arthritis. Arthritis Res Ther. 2018 Jun 8;20(1):123.

[5] Negrotto L, Correale J. Amino Acid Catabolism in Multiple Sclerosis Affects Immune Homeostasis. J Immunol. 2017 Mar 1;198(5):19001909.

[6] Daniela F. de Lima Corvino; Shawn Horrall. Ascariasis Treasure Island (FL): StatPearls Ablishing; 2019 Jan

[7] Andrade MA, Siles-Lucas M, López-Abán J, Carranza C, PérezArellano JL, Muro A. Antigens from Ascaris suum trigger in vitro macrophage NO production. Parasite Immunol. 2005 Jun;27(6):23542 .

[8] Sumbaev VV, Yasinskaya IM Effect of DDT on nitric oxide synthase activity in rat liver, lungs and brain. Sovr. prob. toxicology. 2000. № 3. Р.3-7. (Сумбаев В.В., Ясинская И.М. Влияние ДДТ на активность синтазы оксида азота в печени, легких и головном мозге крыс // Совр. пробл. токсикологии. 2000. № 3. С.3-7.)
[9] Geyer J.W., Dabich D. Rapid method for determination of arginase activity in tissue homogenates. Anal. Biochem. 1971. Vol. 39, № 2. P. 412-417.

[10] Green L. C., David A. W. Analysis of nitrate, nitrite and nitrate in biological fluids. Anal. Biochem. 1982. Vol. 126. P.131-138.

[11] Muro, A. Perez-Arellano, J. L. Nitric oxide and respiratory helminthic diseases. Journal of Biomedicine and Biotechnology 2010, ID 958108

[12] Zhu W, Pryor SC, Putnam J, Cadet P, Stefano GB. Opiate alkaloids and nitric oxide production in the nematode Ascaris suum. J Parasitol. 2004 Feb;90(1):15-22.

[13] Allain AV, Hoang VT, Lasker GF, Pankey EA, Murthy SN, Kadowitz PJ. Role of nitric oxide in developmental biology in plants, bacteria, and man. Curr Top Pharmacol. 2011;15(2):25-33

[14] Ascenzi P, Bocedi A, Gradoni L. The anti-parasitic effects of nitric oxide. IUBMB Life. 2003 Oct-Nov;55(10-11):573-8.

[15] Jan Bradley., Joseph A Jackson Immunity, immunoregulation and the ecology of trichuriasis and ascariasis Parasite Immunology 200426 (11-12):429-41.

[16] Aleinikova TL, Rubtsova GV, Pavlova NA A Guide to Practical Classes in Biochemistry / M .: Medicine, 2000. 128 p. (Алейникова Т.Л., Рубцова Г.В., Павлова Н.А. Руководство к практическим занятиям по биохимии / М.: Медицина, 2000. 128 с.)

[17] Berezantsev Yu.A., Avtushenko EG Helminthological coprological diagnostics. Leningrad: Medicine. Leningrad. Department, 1976. 188 p. (Березанцев Ю.А., Автушенко Е.Г. Гельминтологическая копрологическая діагностика. Ленинград : Медицина. Ленингр. отд-ние, 1976. 188 с.)

[18] Tkach Yu. I., Povgorodnya OI, Zimnitskaya TV, Rzhevskaya OO. Effectiveness of microscopic detection of Enterobius vermicularis eggs on transparent adhesive tape. Bulletin of Taras Shevchenko National University. 2012. T. 243, No. 8. C. 100-106. (Ефективність мікроскопічного виявлення яєць Enterobius vermicularis на прозорій клейкій стрічці / Ю.І. Ткач, О.I Повгородня, Т.В Зімницька, О.О. Ржевська // Вісник ЛНУ імені Тараса Шевченка. 2012. T. 243 , № 8 . C. $100-106$.) 